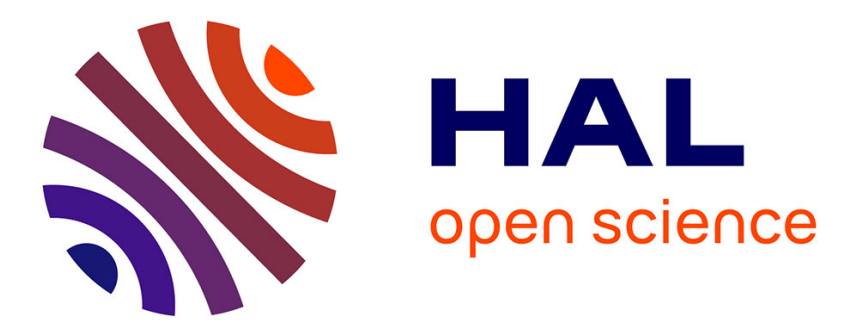

\title{
Investigation of the causes for occurrence of residues of the anticoccidial feed additive nicarbazin in commercial poultry
}

Michael O'Keeffe, Emiliana Capurro, Martin Danaher, Katrina Campbell, Chris Elliott

\section{To cite this version:}

Michael O'Keeffe, Emiliana Capurro, Martin Danaher, Katrina Campbell, Chris Elliott. Investigation of the causes for occurrence of residues of the anticoccidial feed additive nicarbazin in commercial poultry. Food Additives and Contaminants, 2007, 24 (09), pp.923-934. 10.1080/02652030701258778. hal-00577555

\section{HAL Id: hal-00577555 \\ https://hal.science/hal-00577555}

Submitted on 17 Mar 2011

HAL is a multi-disciplinary open access archive for the deposit and dissemination of scientific research documents, whether they are published or not. The documents may come from teaching and research institutions in France or abroad, or from public or private research centers.
L'archive ouverte pluridisciplinaire HAL, est destinée au dépôt et à la diffusion de documents scientifiques de niveau recherche, publiés ou non, émanant des établissements d'enseignement et de recherche français ou étrangers, des laboratoires publics ou privés. 


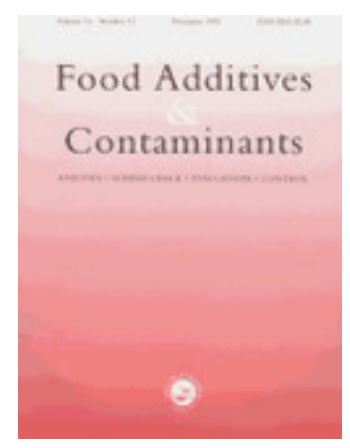

\section{Investigation of the causes for occurrence of residues of the anticoccidial feed additive nicarbazin in commercial poultry}

\begin{tabular}{|r|l|}
\hline Journal: & Food Additives and Contaminants \\
\hline Manuscript ID: & TFAC-2006-341.R1 \\
\hline Manuscript Type: & Original Research Paper \\
\hline Author: & 31-Jan-2007 \\
\hline Complete List of Authors: & $\begin{array}{l}\text { O'Keeffe, Michael; Ashtown Food Research Centre, Teagasc, Food } \\
\text { Safety Department } \\
\text { Capurro, Emiliana; Ashtown Food Research Centre, Teagasc } \\
\text { Danaher, Martin; Ashtown Food Research Centre, Teagasc } \\
\text { Campbell, Katrina; Quens University Belfast } \\
\text { Elliott, Chris; Queens University Belfast }\end{array}$ \\
\hline Methods/Techniques: & Chromatography - HPLC \\
\hline Additives/Contaminants: & Residues \\
\hline Food Types: & Meat \\
\hline & $\quad$ SCHOLARONE \\
\hline & \\
\hline &
\end{tabular}


Michael O'Keeffe ${ }^{1} *$, Emiliana Capurro ${ }^{1}$, Martin Danaher ${ }^{1}$, Katrina Campbell ${ }^{2}$ and

5 Christopher T. Elliott ${ }^{2}$

6

${ }^{1}$ Food Safety Department, Ashtown Food Research Centre, Teagasc, Dunsinea, Ashtown, Dublin 15, Ireland

${ }^{2}$ Institute of Agri-Food \& Land Use, Queen's University Belfast, Stranmillis Road, Belfast BT9 5AG, Northern Ireland

Investigations were undertaken to identify causes for the occurrence of high levels of the zootechnical feed additive nicarbazin in broiler liver at slaughter. The first investigation on 32 commercial broiler flocks involved sampling and analysis for nicarbazin (as dinitrocarbanilide, DNC) in liver from birds during a 3-10 day period after withdrawal of nicarbazin from their feed and prior to commercial slaughter. DNC residues in liver samples of broilers scheduled as being withdrawn from nicarbazin for $\geq 6$ days ranged from 20 to $>1600 \mu \mathrm{g} / \mathrm{kg}$ (the specified withdrawal period for nicarbazin is 5 days and the JECFA MRL is $200 \mu \mathrm{g} / \mathrm{kg}$ liver). Further on-farm investigations on 12 of these flocks, selected on the basis of the feeding system in use and the levels of DNC residues determined in liver, identified issues in feed management contributing to elevated residues in broiler liver. A significant correlation $(0.81, p<0.01, n=10)$ between DNC residues in liver samples and in feed samples from the feeding pans was observed. The second investigation on 12 commercial broiler flocks involved sampling and analysis for DNC in liver samples and feed samples from feeding pans and from the feed mill at the three thinnings of birds for commercial slaughter. In the case of one flock, a clear relationship between nicarbazin in feed from the feed mill $(10.5 \mathrm{mg} / \mathrm{kg} \mathrm{DNC})$, in feed from the feeding pans $(6.6 \mathrm{mg} / \mathrm{kg} \mathrm{DNC})$ and in liver $(583 \mu \mathrm{g} / \mathrm{kg} \mathrm{DNC})$ at first thinning (9 days scheduled withdrawal from nicarbazin) was observed. Such a clear relationship was not observed in other cases, particularly at second and third thinnings, pointing to reexposure of birds to nicarbazin late in the flock production cycle, probably from the litter. Guidelines outlining best farm practice to eliminate nicarbazin residues in poultry have been published in booklet and poster format for broiler producers and deal with feed system cleaning, feed bin management, feed deliveries, feed usage and records.

Keywords: nicarbazin, poultry, commercial production, residues, feed, liver

* To whom correspondence should be addressed. michael.okeeffe@teagasc.ie 


\section{Introduction}

The anticoccidial drug, nicarbazin, is widely used as a zootechnical feed additive in the earlier stages of poultry (broiler) production to prevent coccidiosis caused by species of Eimeria. The commercial product, Maxiban ${ }^{\circledR}$, is a premix product marketed by the company Elanco and contains equal quantities of nicarbazin and the ionophore narasin which act synergistically to prevent coccidiosis. Typically, Maxiban ${ }^{\circledR}$ is incorporated into starter and grower poultry feeds and is provided to birds up to 3-4 weeks of age. The feed additive product is authorised for use at a dosage of $40-50 \mathrm{mg} / \mathrm{kg}$ each of nicarbazin and narasin, with a withdrawal period of 5 days (European Commission 2004). Thereafter, the nicarbazin-medicated feed is replaced with a feed containing an ionophore, such as monensin, and subsequently the birds are fed with finisher feed, containing no anticoccidial feed additives, for a period of some days prior to first thinning at approximately 5 weeks of age (O'Keeffe 2003). The process of "thinning" refers to the removal of a portion of the flock for slaughter; this practice provides birds of a particular weight category for the market and provides additional space for the remaining, larger birds. The commercial slaughtering of a flock may comprise of three thinnings, over a period of approximately 2 weeks; no anticoccidial treatment should occur during the thinnings process.

Nicarbazin is an equimolar mixture of 4,6-dimethyl-2-hydroxypyrimidine (DHP) and 4,4'-dinitrocarbanilide (DNC). The DHP component is excreted rapidly following withdrawal of the drug, but DNC is less rapidly eliminated (Porter and Gilfillan 1955). The FAO/WHO Joint Expert Committee on Food Additives (JECFA) has established $\mathrm{DNC}$ as the marker residue for nicarbazin and has set a maximum residue limit (MRL) for DNC of $200 \mu \mathrm{g} / \mathrm{kg}$ in edible tissues, including muscle and liver (Wells 1999). No MRL has been set for nicarbazin within the European Union, and the JECFA MRL is commonly used as a guideline by the UK and Irish authorities.

The monitoring programmes in the UK and Ireland have identified the occurrence of DNC in poultry liver at levels in excess of the JECFA MRL at an incidence of $17 \%$ to $9 \%$ 
72 of samples tested (Veterinary Residues Committee 2001 to 2005) and of $19 \%$ to $7 \%$ of 73 samples tested (O'Keeffe and Coen 2005, O'Keeffe et al. 2006), respectively. Similarity 74 in the incidence of MRL exceedances determined in the monitoring programmes in the in both jurisdictions. Although there have been decreases in the incidence of noncompliant poultry liver samples in recent years, there is still a substantial problem. While residues of nicarbazin in muscle (poultry meat), as distinct from liver, tend to be of the order of 10-20 times lower, thereby reducing the food safety issue, the occurrence of residues in tissues have given rise to consumer concerns (Young and Craig 2001) and a negative image for the broiler industry. Previous research has identified contamination of ostensibly nicarbazin-free feed during feed manufacturing as a potential source for residues in eggs and in broiler liver (Dorn et al. 1988, Cannavan et al. 2000, Cannavan and Kennedy 2000). In particular, McEvoy et al. (2003) identified practices in feed manufacturing related to recycling of fines and of surplus material from the pelleting process as factors contributing to nicarbazin contamination of withdrawal feed. Another important source for nicarbazin residues in broiler tissues is faeces recycling from litter; Castelli et al. (1989) determined the main source of nicarbazin contamination resulting in residues in the livers of broilers, four weeks after withdrawal of medicated feed, to be the litter on which they were housed. Penz et al. (1999) demonstrated that DNC was detectable in the liver of birds at slaughter from the last of three crops of birds reared on the same litter, where nicarbazin had only been given to the first crop of birds. Cannavan and Kennedy (2000) found that where broilers were fed with nicarbazin according to the product licence conditions, DNC residues in liver exceeding the JECFA MRL of 200 $\mu \mathrm{g} / \mathrm{kg}$ were found in broilers housed on deep litter but not in broilers housed on wire flooring, pointing to faecal recycling from litter as the probable cause.

Therefore, the practices applied in feed manufacturing, feed delivery, feed storage and use and poultry housing are all potential contributors to the problem of nicarbazin residues in broilers in commercial poultry production. A comprehensive study was developed to address this problem on the island of Ireland. Much of the previous research in this area had been undertaken on research flocks in highly-designed and controlled 
103 experiments. In contrast, the research reported here was undertaken with commercial 104 flocks, representing the conditions applying in normal commercial production of broilers. 105 As part of this research, studies with commercial poultry flocks were designed to 106 investigate poultry production practices, particularly feed management, that might be 107 contributing to the high incidence of DNC-positive liver samples at slaughter. These 108 studies encompassed (a) pre-commercial sampling of poultry from commercial flocks 109 together with on-farm visits to some of these flocks to investigate feeding practices and 110 (b) sampling of poultry from selected flocks at each of the commercial thinnings to track 111 the occurrence of nicarbazin residues in poultry at the later stages of the flock production 112 cycle. The aim of the research was to develop knowledge that would be used to produce 113 practical guidelines for poultry producers to assist them in reducing or eliminating the 114 incidence of nicarbazin residues at levels above the JECFA MRL in broiler livers.

115

116

117

118

119

120

121

122

123

124

125

126

127

128

129

130

131

132

133

\section{Experimental}

\section{Sampling at pre-commercial slaughter}

A major poultry company was used for this study. In conjunction with routine testing for Salmonella, representative samples of poultry (livers of five birds) and of feed were obtained from 32 commercial flocks. Each feed sample consisted of a composite of individual feed samples taken from 10 feeding pans in the house at the same time as the poultry livers were sampled. The flocks were selected to be representative of different feeding systems (single bin, split bin, double bin) and to be at that stage of the production cycle where nicarbazin-medicated feed had been withdrawn. The samples of liver and feed were analysed for DNC content by high performance liquid chromatography (HPLC). Investigative visits to 12 selected flocks were made within one week of testing the liver and feed samples. The selection of flocks for further investigation was based on the results of the liver sample analyses (including both low and high levels of DNC) and the type of feeding system(s) in use on the farms. During these visits aspects of the poultry production system were studied and recorded, including, in particular, the feeding system used, feed delivery records and feed management. 


\section{Sampling at commercial thinning}

136 A second major poultry company was used for this study. 12 flocks, representing single bin (2 flocks), split bin (6 flocks) and double bin (4 flocks) feeding systems, were investigated. Samples of liver (livers from five birds) were obtained at commercial slaughter on three occasions, first thinning (approximately 35 days of age), second thinning (approximately 42 days of age) and third thinning (approximately 49 days of age). According to the coccidiosis treatment regime in use by the company, these slaughter times would represent 7,14 and 21 days (approximately) following withdrawal of nicarbazin-containing feed from the birds. On each occasion that the birds were removed at the three thinnings, a sample of feed was collected from the feeding pans (a composite feed sample from 10 feed pans). In addition, the feed samples retained by the company's feed mill for all finisher and withdrawal feeds supplied by the company to the flocks under study were made available for analysis. All samples of liver and of feed from feeding pans and from the feed mill were analysed for DNC content by HPLC.

\section{Analysis of liver and feed samples}

\section{Reagents and chemicals}

DNC standard material was from Sigma-Aldrich (St. Louis, MO, USA). Acetonitrile and methanol (both HiPerSolv grade), dimethylsulphoxide and n-hexane (Analar grade) were obtained from BDH (Merck, Poole, Dorset, UK). Bond Elut ${ }^{\mathrm{TM}}$ cartridges $\left(\mathrm{C}_{18}, 500 \mathrm{mg}, 3\right.$ ml) were from Varian (Harbor City, CA, USA). The primary standard stock solution (1 $\mathrm{mg} / \mathrm{ml}$ ) was prepared in dimethylsulphoxide. Secondary standard stock solutions (100 and $10 \mu \mathrm{g} / \mathrm{ml}$ were prepared by dilution of the primary standard stock in methanol. Calibration standards (50-2000 ng/ml), used to quantify the DNC content in liver and feed samples, were prepared by diluting the $10 \mu \mathrm{g} / \mathrm{ml}$ solution in acetonitrile/water $(80 / 20, v / v)$. The primary stock standard solution was prepared every 3 months and was stored in a glass test-tube covered in aluminium foil at room temperature in the dark; storage at room temperature prevented solidification of the stock solution. Secondary standard stock solutions (in methanol) and calibration standards for HPLC (in acetonitrile/water) were prepared monthly and stored at $4^{\circ} \mathrm{C}$. 
166

167

168

169

170

171

172

173

174

175

176

177

178

179

180

181

182

183

184

185

186

187

188

189

190

191

192

193

194

195

\section{HPLC conditions}

The HPLC system consisted of a model 600E HPLC pump with a model 717 autosampler and model 484 UV detector (set at $350 \mathrm{~nm}$ ), all from Waters (Milford, MA, USA). The separation was carried out on a stainless-steel analytical column $(250 \mathrm{~mm} \times 4.6 \mathrm{~mm}$ i.d. $)$ equipped with a Securiguard ${ }^{\mathrm{TM}}$ pre-column, both packed with Hypersil BDS $\mathrm{C}_{18}$ material (Phenomenex, Cheshire, UK). The column temperature was maintained at $40^{\circ} \mathrm{C}$. The mobile phase, consisting of water/acetonitrile $(55 / 45, \mathrm{v} / \mathrm{v})$, was pumped at $1 \mathrm{ml} / \mathrm{min}$. Under these conditions, the retention time for DNC was approximately $13.5 \mathrm{~min}$. A Waters 746 data processing module was used for recording and processing chromatograms. The injection volume for standards and sample extracts was $25 \mu$.

\section{Liver analyses}

Composite samples of liver (comprising the livers from 5 individual birds) were chopped and mixed thoroughly and a representative subsample taken for analysis. Liver samples were analysed for DNC content according to the method described by Capurro et al (2005). This method involves extraction of a $2 \mathrm{~g}$ liver sample in a $30 \mathrm{ml}$ polypropylene tube by homogenising the sample with $10 \mathrm{ml}$ acetonitrile, using a Polytron ${ }^{\mathrm{TM}}$ homogeniser, vortexing (2 $\mathrm{min})$, sonicating $(3 \mathrm{~min})$ and shaking (15 $\mathrm{min}$ ) before centrifuging $\left(2500 \mathrm{rpm}, 10 \mathrm{~min}, 4^{\circ} \mathrm{C}\right)$ and transferring the supernatant to a clean polypropylene tube. The sample was re-extracted with $5 \mathrm{ml}$ acetonitrile plus $1 \mathrm{ml}$ water and the supernatants combined and defatted using n-hexane $(2 \times 10 \mathrm{ml})$. The acetonitrile layer was evaporated to dryness and reconstituted in acetonitrile/water (70/30, v/v, 500 $\mu 1)$. Sample extracts were purified by passing through $\mathrm{C}_{18}$ SPE cartridges and eluting with $2.5 \mathrm{ml}$ acetonitrile/water $(70 / 30, \mathrm{v} / \mathrm{v})$. The purified extracts were evaporated to dryness under nitrogen $\left(60^{\circ} \mathrm{C}\right)$ and reconstituted in acetonitrile/water $(80 / 20, \mathrm{v} / \mathrm{v}, 500 \mu \mathrm{l})$ for HPLC analysis. Representative chromatograms for liver samples are shown in Figure 1.

Performance of the method during sample testing was evaluated by fortifying control liver samples, in duplicate, with DNC at 25 and $250 \mu \mathrm{g} / \mathrm{kg}$. These quality control samples were included with each batch of test samples; mean recovery of added DNC was 
196 typically $77-114 \%$ for both fortification levels. The limit of determination of the method 197 was $12.5 \mu \mathrm{g} / \mathrm{kg}$, based on the lowest standard in the calibration curve.

198

199

200

201

202

203

204

205

206

207

208

209

210

211

212

213

214

215

216

217

218

219

220

221

222

223

224

225

226

\section{Feed analyses}

Feed samples were mixed thoroughly and representative $20 \mathrm{~g}$ subsamples were ground in a swinging hammer mill (Glen Creston) through a $1 \mathrm{~mm}$ sieve. Following further manual mixing of the ground feed sample, $2.5 \mathrm{~g}$ was weighed into a $50 \mathrm{ml}$ screw-cap polypropylene tube. Feed samples were analysed for DNC content according to the method described by De Jong et al (2004). Water $(5 \mathrm{ml})$ was added to the sample which was mixed and allowed to stand for $10 \mathrm{~min}$, ensuring that the total sample was wetted. Methanol/acetonitrile (50/50, v/v, $35 \mathrm{ml})$ was added to the sample and the contents of the tube were mixed thoroughly by hand. The tube was placed in a water bath $\left(50^{\circ} \mathrm{C}\right)$ for 15 min, with the contents of the tube being mixed thoroughly by hand mid-way through the incubation period. The tube was removed from the water bath and mixed on an end-toend shaker (15 min). Following extraction of the DNC, the tube contents were allowed to settle and the supernatant was removed and filtered through paper filters (Whatman), prior to final filtration through an HPLC sample filter $(0.45 \mu \mathrm{m}$, Acrodisc $\AA$ LC $13 \mathrm{~mm}$ PVDF). An aliquot $(3 \mathrm{ml})$ of the filtered feed sample extract was evaporated to dryness under nitrogen $\left(60^{\circ} \mathrm{C}\right)$ and reconstituted in acetonitrile/water $(80 / 20, \mathrm{v} / \mathrm{v}, 300 \mu \mathrm{l})$ for HPLC analysis. Representative chromatograms for feed samples are shown in Figure 2.

Performance of the method during sample testing was evaluated by fortifying control feed samples, in duplicate, with DNC at 1.6 and $8.0 \mathrm{mg} / \mathrm{kg}$. These quality control samples were included with each batch of test samples; mean recovery \pm standard deviation $(\mathrm{n}=$ 14) of added DNC was $95 \pm 13.3 \%$ and $83 \pm 10.1 \%$ for fortification at 1.6 and 8.0 $\mathrm{mg} / \mathrm{kg}$, respectively. The limit of determination of the method was approximately 0.1 $\mathrm{mg} / \mathrm{kg}$, based on the lowest standard in the calibration curve.

\section{Results}

Studies on poultry during the period prior to commercial slaughter 
227 Table 1 provides data on the samples of poultry liver taken from pre-slaughter flocks,

228

229

230

231

232

233

234

235

236

237

238

239

240

241

242

243

244

245

246

247

248

249

250

251

252

253

254

255

256 representing 32 individual flocks on 23 different farms; the data comprise results for testing for nicarbazin residues in liver and details of the feeding system used for each flock. Measurable nicarbazin residues were determined in all samples of liver taken from the 32 flocks included in the initial study. Nicarbazin residue content of liver samples varied from approximately 20 to $5000 \mu \mathrm{g} / \mathrm{kg}$ DNC. 15 of the 32 liver samples contained nicarbazin residues at concentrations exceeding the JECFA MRL value of $200 \mu \mathrm{g} / \mathrm{kg}$ DNC.

Table 2 provides additional information on those flocks/farms selected for further investigation; selection of flocks/farms for further investigation was based on the results of the pre-slaughter sample analysis (including both low and high levels of nicarbazin) and the type of feeding system(s) in use on the farms. Data for the 12 poultry flocks, on 8 farms, selected for further study, showed that 10 of these poultry flocks were scheduled as being on nicarbazin-free feed for between 6 and 10 days, i.e. 1 to 5 days longer than the specified withdrawal period of five days (Table 2). Liver samples from 4 of these 10 flocks contained nicarbazin residues in excess of $200 \mu \mathrm{g} / \mathrm{kg}$ DNC (Figure 3), indicating that for these flocks, in particular, the withdrawal period was not effective and that on these farms there was continued exposure of birds to nicarbazin for extended periods after feed changeover. Samples of feed taken from the feeding pans on which the birds were feeding at pre-commercial slaughter sampling were analysed for nicarbazin (Table 2). For birds that were scheduled as being withdrawn from nicarbazin-containing feed for periods of 6 to 10 days, residue levels in liver were generally related (correlation coefficient 0.81 , $\mathrm{p}<0.01, \mathrm{n}=10$ ) to drug concentration in the feed from feeding pans; in the exceptional case of farm/flock O2, the relatively high nicarbazin content in the feeding pan was not reflected by a high liver content of nicarbazin. Elevated drug concentration in feed at 6 to 10 days after planned feed changeover, resulting in elevated nicarbazin residue in liver, indicates significant feed contamination in these feeding systems. For farm/flock $\mathrm{C} 1$ and L2, where the scheduled times off nicarbazin-medicated feed were 4 and 3 days, respectively, only in the case of farm/flock L2 was a high liver nicarbazin residue content 
257

258

259

260

261

262

263

264

265

266

267

268

269

270

271

272

273

274

275

276

277

278

279

280

281

282

283

284

285

286

287

associated with a high feed nicarbazin. For farm/flock $\mathrm{C} 1$, the elevated liver nicarbazin residue may have been related to drug persistence.

The on-farm investigations did not show clear relationships between the feeding system used (5 double bin, 5 single bin, 2 split bin), including the presence and type of hopper, and the nicarbazin residue levels determined in flocks. There was a tendency for liver samples from flocks with single bin systems to have a greater incidence of relatively high concentrations of nicarbazin residue, but high levels of nicarbazin residue in preslaughter liver samples were associated, also, with double bin and split bin systems. The on-farm investigations strongly suggested that the feed management system used on the particular farm may be the most important issue in determining whether birds remain exposed to nicarbazin following feed changeover.

\section{Studies on poultry at commercial slaughter}

Complete details for the farms/flocks included in the study are shown in Table 3, including type of feeding system used and, for each of the three commercial thinnings, scheduled number of days withdrawal from nicarbazin-containing feed and nicarbazin content determined in samples of feed from the feed mill, feed from the feeding pans and liver from the slaughtered birds. Of the 36 samples of feed (both feed mill and feeding pan samples) and liver targeted for sampling, in total 32 samples of liver, 30 samples of feed from feeding pans and 25 samples of feed from the feed mill were received for analysis.

\section{Results for first thinnings}

Nicarbazin residue was determined in all samples taken at the first thinning, ranging in concentration from 25 to $600 \mu \mathrm{g} / \mathrm{kg}$ DNC. These samples were from birds that had been scheduled as being withdrawn from nicarbazin for 6 days or more. No pattern of nicarbazin residue in liver being related to feeding system was discernible; the three samples containing nicarbazin residue in excess of $200 \mu \mathrm{g} / \mathrm{kg}$ DNC were each from single, split and double bin systems. Where samples of feed from the feeding pans were available, there was a relationship between nicarbazin residue in liver and nicarbazin in 
288 feed. The two highest liver samples, $583 \mu \mathrm{g} / \mathrm{kg}$ DNC (farm/flock EE2) and $292 \mu \mathrm{g} / \mathrm{kg}$

289 DNC (farm/flock HH1) were associated with feed nicarbazin levels of $6.6 \mathrm{mg} / \mathrm{kg}$ DNC 290 and $0.81 \mathrm{mg} / \mathrm{kg} \mathrm{DNC}$, respectively. All other liver samples (containing 25 - $128 \mu \mathrm{g} / \mathrm{kg}$ 291 DNC) were associated with feed nicarbazin levels of not detectable (ND) to $0.42 \mathrm{mg} / \mathrm{kg}$ 292 DNC.

293

294 Only in one case (farm/flock EE2) was a potential linkage from nicarbazin residue in 295 liver $(583 \mu \mathrm{g} / \mathrm{kg}$ DNC) through nicarbazin in feed in the feeding pans $(6.6 \mu \mathrm{g} / \mathrm{kg} \mathrm{DNC})$ to 296 nicarbazin in feed supplied by the feed mill (10.5 $\mathrm{gg} / \mathrm{kg} \mathrm{DNC})$ discernible. Interestingly, 297 the same batch of feed from the feed mill was supplied to another flock on this farm 298 (EE1), into a split bin system. In this case, the birds were slaughtered one day earlier and 299 nicarbazin residue in liver $(124 \mu \mathrm{g} / \mathrm{kg}$ DNC) and feed in the feeding pans $(0.36 \mathrm{mg} / \mathrm{kg}$ 300 DNC) were considerably lower. These differences in nicarbazin content between birds 301 (liver samples) and feeding pan feeds for the two flocks on the same farm may be due to 302 the different feeding systems used for the two flocks and/or may indicate that the feed 303 mill sample, containing $10.5 \mathrm{mg} / \mathrm{kg}$ DNC, may not be representative of the total feed 304 delivery, particularly the feed delivered to farm/flock EE1.

305

306

307

308

309

310

311

312

313

314

315

316

317

318

\section{Results for second and third thinnings}

Nicarbazin residue levels in liver from birds taken at the second thinnings were lower, generally, than levels in birds from the first thinnings, ranging in concentration from ND to $208 \mu \mathrm{g} / \mathrm{kg}$ DNC. These samples were from birds that had been scheduled as being withdrawn from nicarbazin for 11-19 days. The associated feed from feeding pans showed corresponding lower nicarbazin levels, also, ranging from ND to $0.25 \mathrm{mg} / \mathrm{kg}$ DNC. Some relatively high levels of nicarbazin residue in liver from birds taken in the second thinnings, for example farm/flock BB1 (208 $\mu \mathrm{g} / \mathrm{kg}$ DNC), CC1 (135 $\mu \mathrm{g} / \mathrm{kg}$ DNC) and GG1 (129 $\mu \mathrm{g} / \mathrm{kg}$ DNC), could not be explained by the levels of nicarbazin determined in the corresponding feed samples. These results suggest some alternative source of nicarbazin to the birds, particularly since birds from these flocks showed lower liver nicarbazin residue levels at first thinning. 
319 The results for samples from the third thinnings show no further decrease in liver nicarbazin concentration overall, ranging from ND to $195 \mu \mathrm{g} / \mathrm{kg}$ DNC. Samples of the feed supplied by the feed mill show generally similar nicarbazin contents as were found in feed being fed to birds at the time of second thinnings, i.e. ND to $0.24 \mathrm{mg} / \mathrm{kg} \mathrm{DNC}$. However, the nicarbazin content in feed samples from feeding pans was relatively high in some cases, such as farm/flock AA1 (7.1 mg/kg DNC) and farm/flock BB1 $(0.60 \mathrm{mg} / \mathrm{kg}$ DNC), and, overall, was higher than the levels found in feeding pan samples at the second thinnings. These elevated nicarbazin levels in feeding pan samples may be caused by older, nicarbazin-medicated feed in the feeding system and at the bottom of feeding pans becoming available when the cycle of poultry production is finishing. For a number of farms/flocks, such as AA1, FF1, JJ1, there appears to be a re-contamination of poultry with nicarbazin between the second and third thinnings, not always related to the nicarbazin level determined in the feed samples from the feeding pans. As was observed for the second thinnings, these latter findings suggest an alternative source of nicarbazin contamination to the birds.

\section{Discussion}

The pre-commercial slaughter sampling and the follow-on investigations on farms identified the following issues as important contributors to exposure of birds to nicarbazin following feed changeover:

(a) poor understanding by some farmers of the different feed types (nicarbazin-medicated feed, ionophore-medicated feed and non-medicated withdrawal feed) and the necessity not to mix them

(b) poor communication between feed supply and farms; in some cases it was found that feed deliveries were made before bins were empty, and identification of bins in double bin systems or of compartments in split bin systems appeared to be deficient

(c) poor management of feed bins on farms; in some cases rotation of bins and/or compartments for the different deliveries of feed did not appear to be based on the feed additive contents and the need to avoid cross-contamination 
349

350

351

352

353

354

355

356

357

358

359

360

361

362

363

364

365

366

367

368

369

370

371

372

373

374

375

376

377

378

379

(d) deficient cleaning and checking (that is, visual inspection of feed bins/hoppers for lodged feed) of feeding equipment between feed changeovers; in some cases even where bins were emptied before feed changeover, hoppers and feeding lines might not be emptied - the importance of this aspect was identified by the thorough cleaning practice observed on one farm with a single bin system (farm/flock E1) for which the pre-slaughter sampling, at 6 days off nicarbazin-medicated feed, showed a very low level of nicarbazin residue in liver.

The second study, involving analysis for nicarbazin of poultry liver and feed samples from the feeding pans and from the feed mill at the three commercial thinnings for 12 farms/flocks, gives some interesting insights into the potential causes for nicarbazin residue in broilers at slaughter. In one case (farm/flock EE2, first thinning), there was a clear "cause and effect" relationship between contaminated feed supplied from the feed mill, contaminated feed on farm and relatively high nicarbazin residue levels in liver. Relatively high nicarbazin residue levels were determined in poultry liver from some farms/flocks at each of the three thinnings but there does not appear to be a consistent pattern for individual farms/flocks across the three thinnings, nor any clear relationship with feeding system used (single bin, split bin, double bin). The results obtained at the second and, especially, at the third thinnings are particularly difficult to explain and appear to point to issues such as (a) re-contamination of birds with nicarbazin and (b) feed samples taken from feeding pans not being representative of what the birds were consuming at time of third thinning. These latter results suggest that birds may be exposed to alternative sources of nicarbazin close to slaughter, such as older nicarbazinmedicated feed from the feeding system or from the litter (Cannavan and Kennedy, 2000).

The aim of the investigations was to obtain comprehensive knowledge in commercial poultry production systems on the causes for nicarbazin occurring in poultry at slaughter and to use this knowledge to develop guidelines for poultry producers on prevention of nicarbazin residues in broilers. Multiple potential causes for nicarbazin residues occurring in edible tissues of birds at slaughter were identified, including contamination of feed at 
the feed mill or during transport, supply of incorrect feed type, delivery of feed into incorrect feed bin, inadequate cleaning of feeding system on farm prior to feed delivery and feed changeover, inadequate withdrawal periods being observed, poor management

\section{References}

Cannavan, A., Ball, G. and Kennedy, D.G., 2000, Nicarbazin contamination in feeds as a cause of residues in eggs. Food Additives and Contaminants, 17, 829-836.

Cannavan, A. and Kennedy, D.G., 2000, Possible causes of nicarbazin residues in chicken tissues. Food Additives and Contaminants, 17, 1001-1006.

Capurro, E., Danaher, M., Anastasio, A., Cortesi M. L. and O'Keeffe, M., 2005, Efficient HPLC method for the determination of nicarbazin, as dinitrocarbanilide in broiler liver. Journal of Chromatography B, 822, 154 - 159.

Castelli, S., Brambilla, G.F., Riberzani, A. And Macri, A., 1989, Nicarbazina: deplezione della componente DNC dal tessuto muscolare ed epatico di broilers. Industrie Alimentari, 28, 947-949.

De Jong, J., Tomassen, M., Driessen, J., Keukens, H., Putzka, H.-A. and Brambilla, G., 2004, Liquid chromatographic method for nicarbazin in broiler feeds and premixtures: development, validation, and interlaboratory study. Journal of AOAC International, 87, 1269-1277.

Dorn, P., Neudegger, J. and Knoppler, H.O., 1988, Zur problematic der wirkstoffverschleppung bei der mischfutterherstellung am beispiel nicarbazin. Tierarztliche Umschau, 43, 524-529.

European Commission 2004/C 50/01, 25 February 2004, List of the authorised additives in feedingstuffs published in application of article 9t (b) of Council Directive 
432

433

434

435

436

437

438

439

440

441

442

443

444

445

446

447

448

449

450

451

452

453

454

455

456

457

458

459

460

461

462

463

464

465

70/524/EEC concerning additives in feedingstuffs. Official Journal of the European Union, C50, 12.

McEvoy, J.D.G., Smyth, W.G. and Kennedy, D.G., 2003, Contamination of animal feedingstuffs with nicarbazin: investigations in a feed mill. Food Additives and Contaminants, 20, 136-140.

O'Keeffe, M., 2003. A Review of Coccidiostat Residues in Poultry, safefood, Food Safety Promotion Board, Cork, $37 \mathrm{pp}$.

O'Keeffe, M. and Coen, K., 2005. National Food Residue Database Report 2005, Teagasc, Dublin, ISBN: 184170397 4, 57 pp.

O'Keeffe, M., 2006. Prevention of nicarbazin residues in broilers: guidelines for poultry producers, safefood - the Food Safety Promotion Board, Cork, 6pp.

O'Keeffe, M., Rehmann, F.J. and Coen, K., 2006. National Food Residue Database Report 2006, Teagasc, Dublin, ISBN: 184170462 3, 60 pp.

Penz, A.M.Jr., Vieira, S.L. and Ludke, J.V., 1999, Nicarbazin residues in broiler tissue and litter. Journal of Applied Poultry Science, 8, 292-297.

Porter, C.C. and Gilfillan, J.L., 1955, The absorption and excretion of orally administered nicarbazin by chickens. Poultry Science, 34, 995-1001.

Veterinary Residues Committee, 2001. Annual Report on Surveillance for Veterinary Residues in Food in the UK 2001, Veterinary Residues Committee, Surrey, UK, 36 pp.

Veterinary Residues Committee, 2002. Annual Report on Surveillance for Veterinary Residues in Food in the UK 2002, Veterinary Residues Committee, Surrey, UK, 44 pp.

Veterinary Residues Committee, 2003. Annual Report on Surveillance for Veterinary Residues in Food in the UK 2003, Veterinary Residues Committee, Surrey, UK, 48 pp.

Veterinary Residues Committee, 2004. Annual Report on Surveillance for Veterinary Residues in Food in the UK 2004, Veterinary Residues Committee, Surrey, UK, 56 pp.

Veterinary Residues Committee, 2005. Annual Report on Surveillance for Veterinary Residues in Food in the UK 2005, Veterinary Residues Committee, Surrey, UK, 48 pp.

Wells, R.J., 1999, Wells, Nicarbazin. In FAO Food and Nutrition Paper 41/11, Food and Agriculture Organisation of the UN, Rome, 83-93.

Young, R. and Craig, A., 2001. Too Hard to Swallow - the truth about drugs and poultry, Soil Association, Bristol, UK, 66 pp. 
466

467 Acknowledgements

468 The authors would like to acknowledge safefood, the Food Safety Promotion Board, for 469 funding this project. The co-operation of the two poultry companies, and their associated 470 poultry producers, with the investigations is gratefully acknowledged. Dr. Lynsey Dunne 471 is thanked for her assistance with the project. 


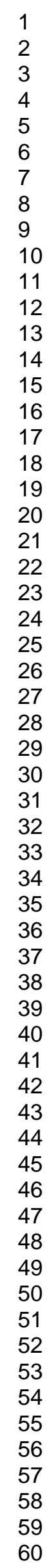


Table 1. Results of pre-commercial slaughter testing for nicarbazin in poultry flocks by HPLC

\begin{tabular}{|c|c|c|c|}
\hline Farm/Flock & Feeding system & $\begin{array}{c}\text { Nicarbazin } \\
\text { (DNC, } \mu \mathrm{g} / \mathrm{kg})\end{array}$ & \\
\hline $\mathrm{A} 1$ & double bin & 86 & \\
\hline B2 & double bin & 68 & $*$ \\
\hline $\mathrm{C} 1$ & single bin & 865 & $*$ \\
\hline D1 & single bin & 1119 & $*$ \\
\hline D2 & split bin & 106 & $*$ \\
\hline D3 & double bin & 33 & $*$ \\
\hline E1 & single bin & 19 & $*$ \\
\hline $\mathrm{F} 1$ & single bin & 139 & \\
\hline $\mathrm{F} 2$ & double bin & 51 & \\
\hline G1 & double bin & 31 & \\
\hline $\mathrm{G} 2$ & double bin & 97 & \\
\hline $\mathrm{H} 1$ & double bin & 354 & \\
\hline I1 & double bin & 210 & \\
\hline $\mathrm{J} 1$ & double bin & 109 & \\
\hline K1 & single bin & 419 & $*$ \\
\hline L1 & double bin & 48 & \\
\hline L2 & single bin & 1592 & $*$ \\
\hline M1 & single bin & 241 & \\
\hline N1 & double bin & 85 & \\
\hline $\mathrm{O} 2$ & double bin & 47 & $*$ \\
\hline $\mathrm{O} 3$ & double bin & 50 & $*$ \\
\hline $\mathrm{P} 2$ & double bin & 243 & \\
\hline Q1 & double bin & 251 & \\
\hline $\mathrm{R} 2$ & double bin & 112 & \\
\hline $\mathrm{S} 1$ & double bin & 354 & \\
\hline $\mathrm{T} 2$ & double bin & 4897 & \\
\hline U1 & double bin & 44 & \\
\hline U2 & double bin & 359 & \\
\hline V1 & double bin & 609 & $*$ \\
\hline $\mathrm{V} 2$ & split bin & 1624 & $*$ \\
\hline W1 & single bin & 121 & \\
\hline W2 & double bin & 224 & \\
\hline
\end{tabular}

* Farms selected for further investigation. 
Table 2. Details for farms/flocks subjected to further investigation

\begin{tabular}{|c|c|c|c|c|}
\hline $\begin{array}{l}\text { Farm/ } \\
\text { Flock }\end{array}$ & $\begin{array}{c}\text { Nicarbazin } \\
\text { residue in } \\
\text { liver } \\
(\mathrm{DNC} \\
\mu \mathrm{g} / \mathrm{kg})\end{array}$ & Feeding system details & $\begin{array}{c}\text { Scheduled } \\
\text { days } \\
\text { withdrawal } \\
\text { from } \\
\text { medicated } \\
\text { feed }\end{array}$ & $\begin{array}{c}\text { Nicarbazin } \\
\text { in feed } \\
\text { (DNC, } \\
\text { mg/kg) }\end{array}$ \\
\hline $\mathrm{B} 2$ & 68 & double bin (separate hopper) & 10 & 0.26 \\
\hline $\mathrm{C} 1$ & 865 & single bin (no hopper) & 4 & 1.2 \\
\hline D1 & 1119 & single bin (separate hopper, old feeders) & 7 & 4.9 \\
\hline D2 & 106 & split bin (separate hopper) & 7 & 0.67 \\
\hline D3 & 33 & double bin (separate hopper) & 8 & 0.14 \\
\hline $\mathrm{E} 1$ & 19 & single bin (no hopper) & 6 & 0.48 \\
\hline K1 & 419 & single bin (hopper in/under bin) & 6 & 9.2 \\
\hline L2 & 1592 & single bin (hopper in/under bin) & 3 & 22.6 \\
\hline $\mathrm{O} 2$ & 47 & double bin (hopper in/under bin) & 9 & 2.9 \\
\hline $\mathrm{O} 3$ & 50 & double bin (hopper in/under bin) & 6 & 0.70 \\
\hline $\mathrm{V} 1$ & 609 & double bin (hopper in/under bin) & 9 & 3.4 \\
\hline $\mathrm{V} 2$ & 1624 & split bin (hopper in/under bin) & 9 & 11.0 \\
\hline
\end{tabular}




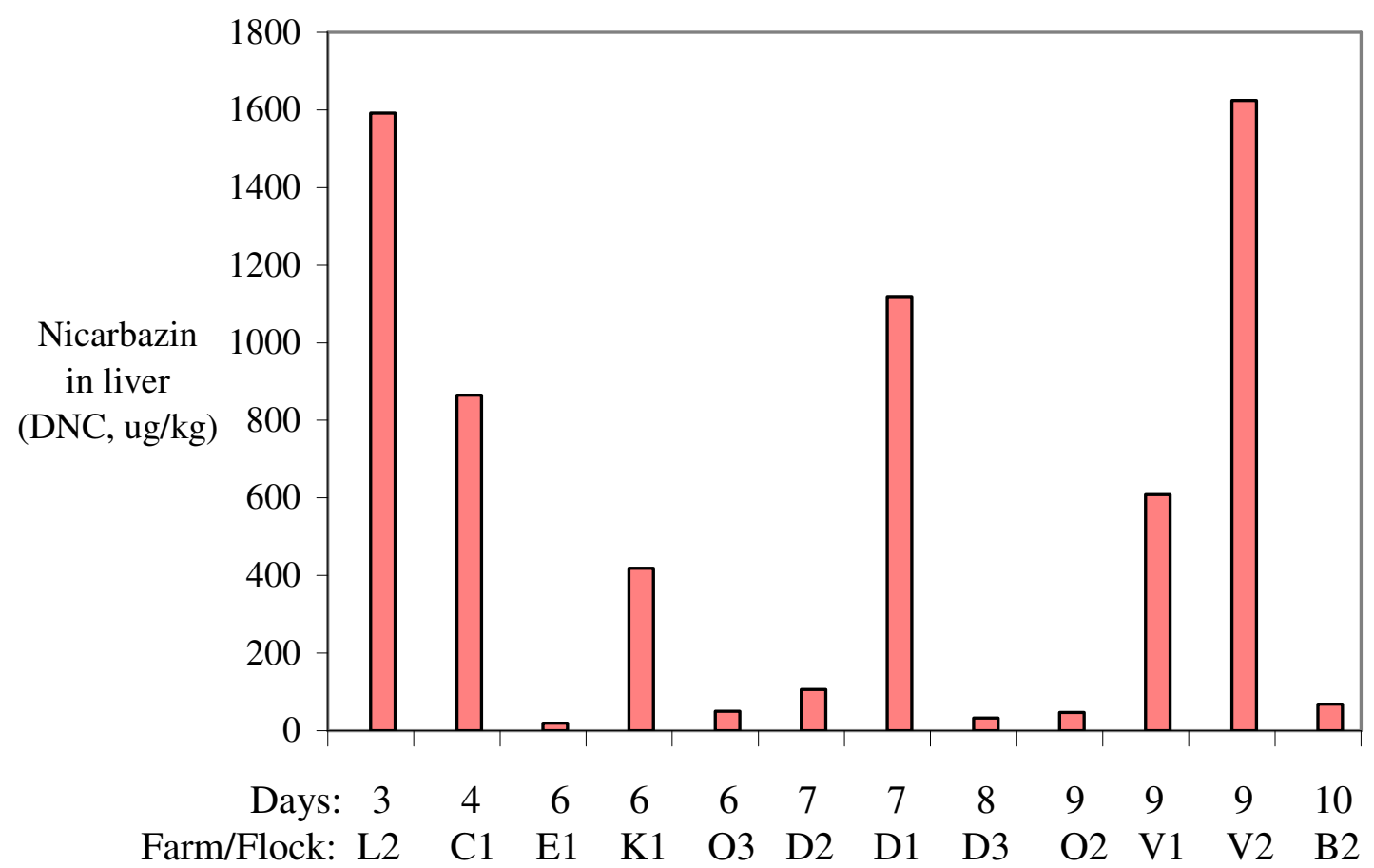

Figure 3. Nicarbazin residue levels in poultry liver samples as a function of scheduled time of withdrawal from medicated feed 
Table 3. Details of samples taken and nicarbazin content in feed and liver samples

\begin{tabular}{|c|c|c|c|c|c|c|c|c|c|c|c|c|c|}
\hline \multirow[b]{3}{*}{$\begin{array}{l}\text { Farm/ } \\
\text { Flock }\end{array}$} & \multirow{3}{*}{$\begin{array}{l}\text { Feeding } \\
\text { system } \\
\text { (bin } \\
\text { type) }\end{array}$} & \multicolumn{4}{|c|}{ First thinning } & \multicolumn{4}{|c|}{ Second thinning } & \multicolumn{4}{|c|}{ Third thinning } \\
\hline & & \multirow[b]{2}{*}{$\begin{array}{l}\text { Scheduled } \\
\text { days off } \\
\text { Nicarbazin }\end{array}$} & \multicolumn{3}{|c|}{ Nicarbazin (DNC) } & \multirow[b]{2}{*}{$\begin{array}{l}\text { Scheduled } \\
\text { days off } \\
\text { Nicarbazin }\end{array}$} & \multicolumn{3}{|c|}{ Nicarbazin (DNC) } & \multirow[b]{2}{*}{$\begin{array}{l}\text { Scheduled } \\
\text { days off } \\
\text { Nicarbazin }\end{array}$} & \multicolumn{3}{|c|}{ Nicarbazin (DNC) } \\
\hline & & & $\begin{array}{c}\text { Feed } \\
\text { mill } \\
(\mathrm{mg} / \mathrm{kg})\end{array}$ & $\begin{array}{c}\text { Feed } \\
\text { pan } \\
(\mathrm{mg} / \mathrm{kg})\end{array}$ & $\begin{array}{c}\text { Liver } \\
(\mu \mathrm{g} / \mathrm{kg})\end{array}$ & & $\begin{array}{c}\text { Feed } \\
\text { mill } \\
(\mathrm{mg} / \mathrm{kg})\end{array}$ & $\begin{array}{c}\text { Feed } \\
\text { pan } \\
(\mathrm{mg} / \mathrm{kg})\end{array}$ & $\begin{array}{c}\text { Liver } \\
(\mu \mathrm{g} / \mathrm{kg})\end{array}$ & & $\begin{array}{c}\text { Feed } \\
\text { mill } \\
(\mathrm{mg} / \mathrm{kg})\end{array}$ & $\begin{array}{c}\text { Feed } \\
\text { pan } \\
(\mathrm{mg} / \mathrm{kg})\end{array}$ & $\begin{array}{c}\text { Liver } \\
(\mu \mathrm{g} / \mathrm{kg})\end{array}$ \\
\hline AA1 & Split & 9 & ND & 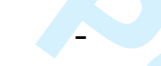 & 293 & 16 & ND & 0.12 & 44 & 21 & - & 7.1 & 97 \\
\hline BB1 & Split & 6 & ND & - & 101 & 11 & 0.70 & 0.25 & 208 & 21 & ND & 0.60 & ND \\
\hline $\mathrm{CC} 1$ & Double & 6 & ND & ND & 45 & 13 & ND & ND & 135 & 19 & 0.24 & 0.17 & 55 \\
\hline DD1 & Single & 7 & - & ND & 27 & 19 & 0.24 & ND & ND & - & - & - & - \\
\hline DD2 & Double & 7 & - & 0.17 & 25 & 15 & - & ND & ND & - & - & - & - \\
\hline EE1 & Split & 8 & 10.5 & 0.36 & 124 & 15 & 0.12 & ND & 37 & 21 & 0.24 & 0.24 & 31 \\
\hline EE2 & Double & 9 & 10.5 & 6.6 & 583 & 16 & 0.12 & ND & ND & 21 & 0.24 & ND & 16 \\
\hline FF1 & Split & 9 & 0.70 & 0.17 & 128 & 19 & $\mathrm{ND}$ & ND & 36 & 23 & ND & 0.31 & 106 \\
\hline GG1 & Double & 8 & ND & ND & 65 & 15 & ND & ND & 129 & 17 & ND & 0.29 & 15 \\
\hline HH1 & Single & 7 & 0.12 & 0.81 & 292 & - & - & - & - & 20 & - & 0.44 & 31 \\
\hline II1 & Split & 9 & - & 0.42 & 64 & 15 & - & ND & ND & 23 & ND & ND & 44 \\
\hline $\mathrm{JJ} 1$ & Split & - & - & - & - & 15 & ND & ND & 44 & 22 & ND & ND & 195 \\
\hline
\end{tabular}

ND: No residue detected (limits of determination $0.1 \mathrm{mg} / \mathrm{kg}$ in feed, $25 \mu \mathrm{g} / \mathrm{kg}$ in liver)

- : Sample not available for analysis 


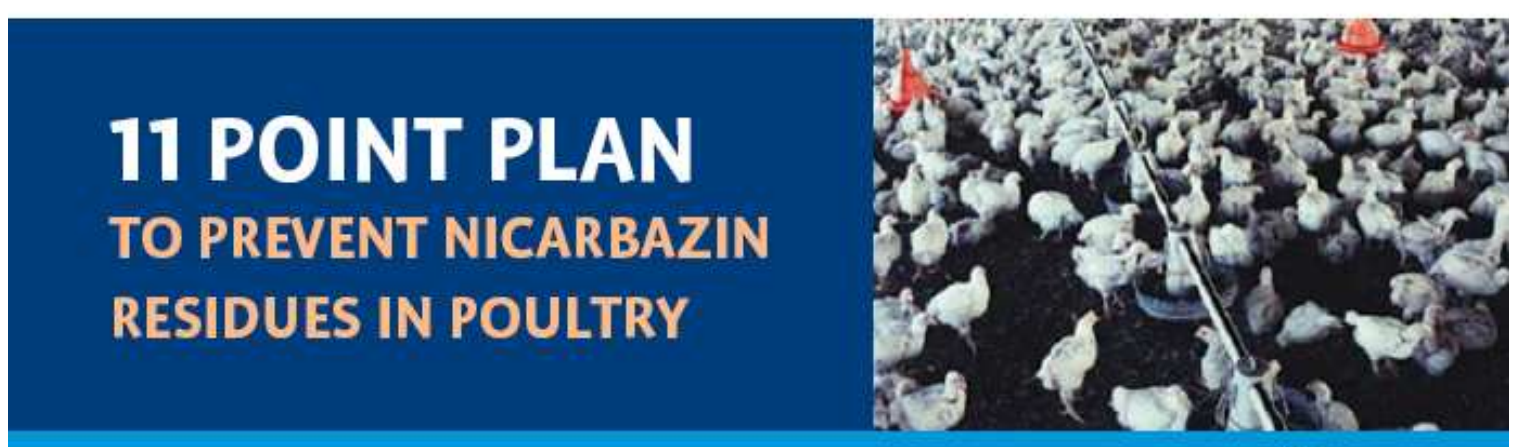

\begin{tabular}{|ll|}
\hline 1 & Clearly number all feed bins, including each side of split bins. \\
\hline 2 & $\begin{array}{l}\text { Empty and clean the total feeding system - feed bins, hoppers, } \\
\text { feed lines, feed pans - before delivery of Nicarbazin-free feed. }\end{array}$ \\
\hline 3 & Check that there is no lodging of feed in bins, hoppers and feed pans. \\
\hline 4 & $\begin{array}{l}\text { Clearly specify the feed bin that is to receive the feed delivery and } \\
\text { lock all other bins. }\end{array}$ \\
\hline 5 & \begin{tabular}{l} 
Take and store a sample of each feed delivered. \\
\hline 6
\end{tabular}$\quad \begin{array}{l}\text { Follow a planned rotation of feed bins to prevent mixing of } \\
\text { Nicarbazin-free feed with Nicarbazin-containing feed. }\end{array}$ \\
\hline 7 & $\begin{array}{l}\text { Prevent feed spillage into litter and clean up any Nicarbazin-containing } \\
\text { feed that has spilled. }\end{array}$ \\
\hline 8 & $\begin{array}{l}\text { Ensure that all Nicarbazin-containing feed in feed pans is consumed by } \\
\text { withdrawing feed from the birds for a period before the changeover to } \\
\text { Nicarbazin-free feed. }\end{array}$ \\
\hline 9 & $\begin{array}{l}\text { Ensure that birds do not receive Nicarbazin-containing feed again after } \\
\text { they have been changed to Nicarbazin-free feed. }\end{array}$ \\
\hline 10 & $\begin{array}{l}\text { Ensure that thinning of birds for slaughter is scheduled so that the full } \\
\text { withdrawal period of } 5 \text { days off Nicarbazin-containing feed is observed. }\end{array}$ \\
\hline 11 maintain accurate records on feed deliveries, feed usage and thinnings. \\
\hline
\end{tabular}

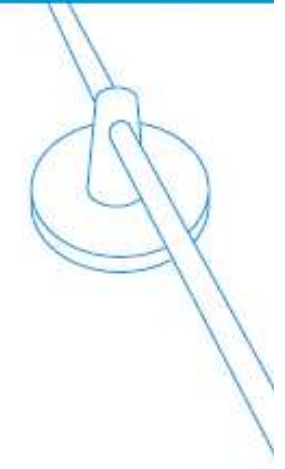

\section{W) safefood}

\section{TO PREVENT NICARBAZIN} RESIDUES IN POULTRY

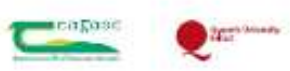

Figure 4. Poster with 11-point plan to prevent nicarbazin residues in poultry 


\section{safefood 11 POINT PLAN TO PREVENT NICARBAZIN RESIDUES IN POULTRY}

1. Clearly number all feed bins, including each side of split bins.

2. Empty and clean the total feeding system - feed bins, hoppers, feed lines, feed pans - before delivery of Nicarbazin-free feed.

3. Check that there is no lodging of feed in bins, hoppers and feed pans.

4. Clearly specify the feed bin that is to receive the feed delivery and lock all other bins.

5. Take and store a sample of each feed delivered.

6. Follow a planned rotation of feed bins to prevent mixing of Nicarbazin-free feed with Nicarbazin-containing feed.

7. Prevent feed spillage into litter and clean up any Nicarbazincontaining feed that has spilled.

8. Ensure that all Nicarbazin-containing feed in feed pans is consumed by withdrawing feed from the birds for a period before the changeover to Nicarbazin-free feed.

9. Ensure that birds do not receive Nicarbazin-containing feed again after they have been changed to Nicarbazin-free feed.

10.Ensure that thinning of birds for slaughter is scheduled so that the full withdrawal period of 5 days off nicarbazin-containing feed is observed.

11.Maintain accurate records on feed deliveries, feed usage and thinnings.

Figure 4. Safefood 11-point plan to prevent nicarbazin residues in poultry 
A
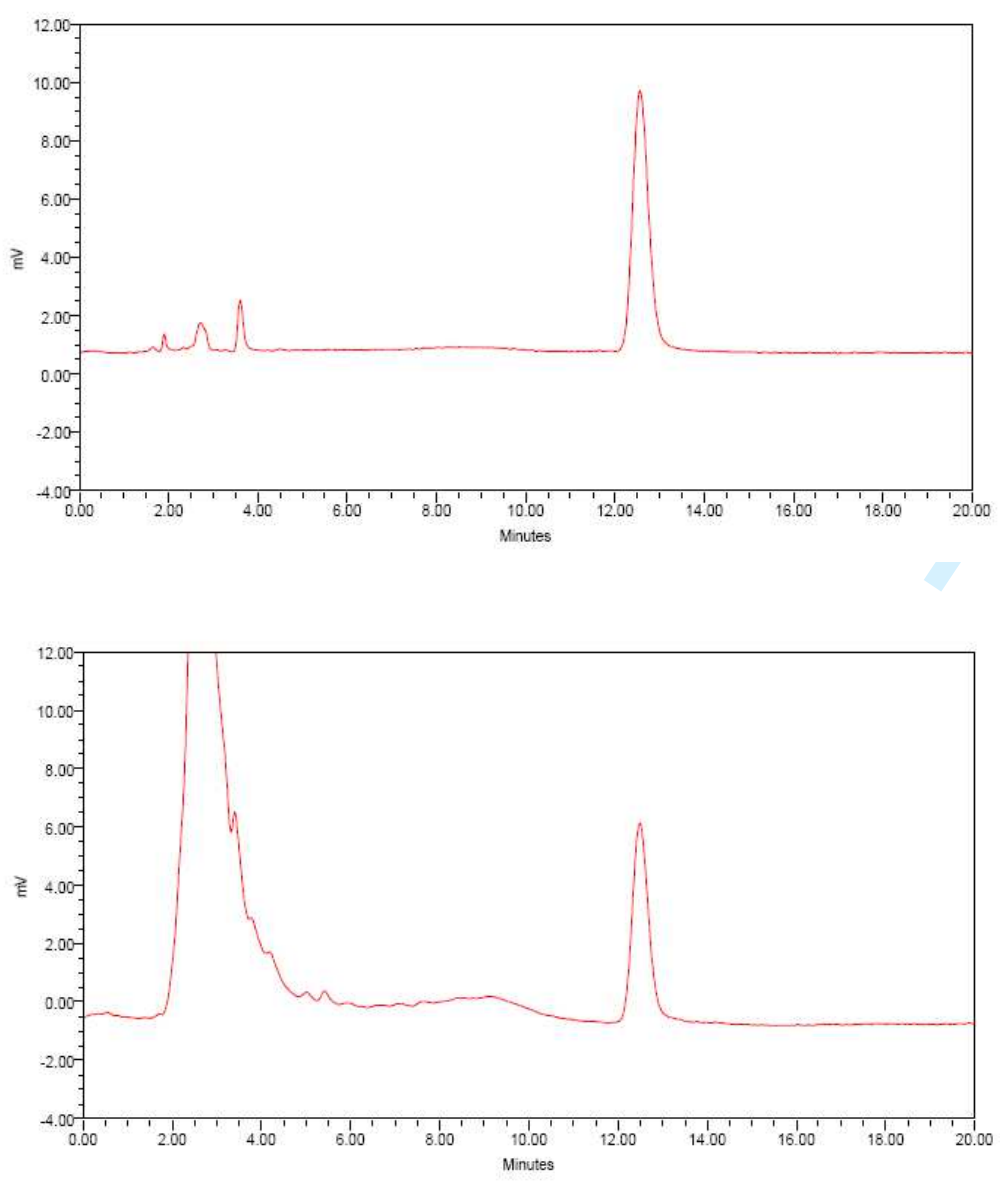

C

Figure 1. Representative chromatograms for DNC in liver samples, retention time 12.5 min (A: DNC standard $1000 \mathrm{ng} / \mathrm{ml}$; B: Control liver sample; C: Control liver sample fortified with DNC at $250 \mu \mathrm{g} / \mathrm{kg}$; D: Test liver sample containing $300 \mu \mathrm{g} / \mathrm{kg}$ DNC) 
A

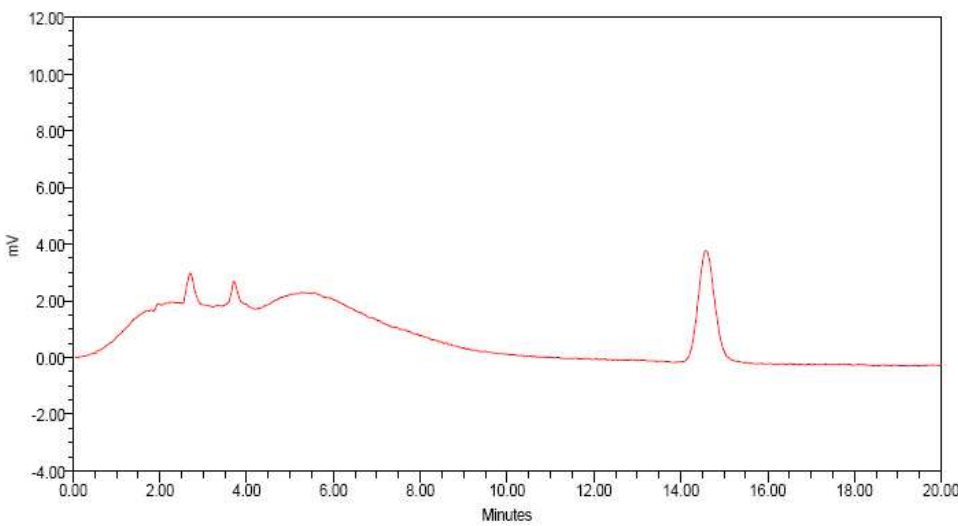

C

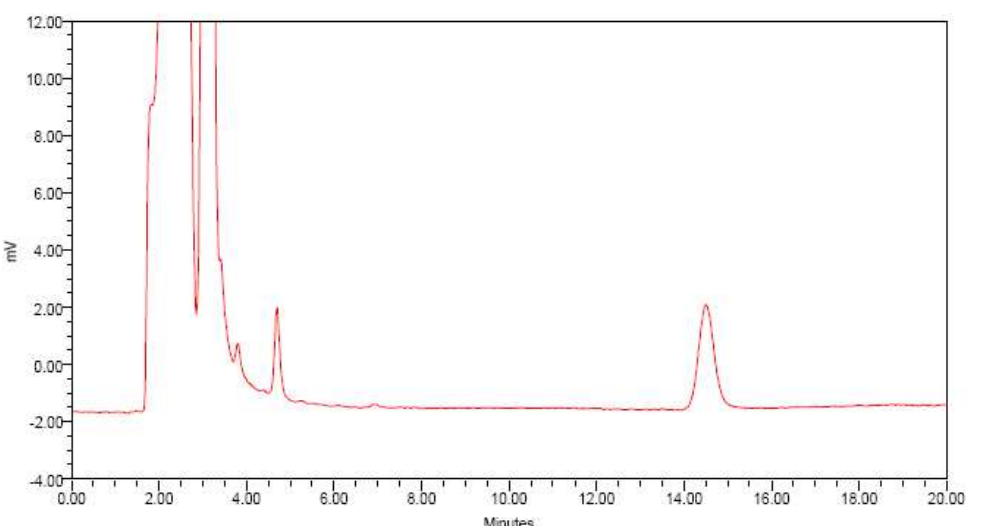

Figure 2. Representative chromatograms for DNC in feed samples, retention time $14.5 \mathrm{~min}$ (A: DNC standard $500 \mathrm{ng} / \mathrm{ml}$; B: Control feed sample; C: Control feed sample fortified with DNC at $8.0 \mathrm{mg} / \mathrm{kg}$; D: Test feed sample containing $7.5 \mathrm{mg} / \mathrm{kg}$ DNC) 